\title{
United Nations Authorized Embargos and Maritime Interdiction: A Special Focus on Somalia
}

\author{
Magne Frostad
}

\section{Introduction}

Somewhat less known than the UN Security Council (UNSC) resolutions on Somali piracy are its resolutions on a weapons embargo of that state-an embargo established due to the anarchy ruling in Somalia after the fall of Dictator Siad Barre. ${ }^{1}$ Resolutions have been adopted on this topic since $1992^{2}$ without much effect as no proper enforcement regime has been authorized. This flow of weapons and ammunition has not only helped to arm the factions that fought for supremacy in Somalia but has most certainly also helped the organizers of piracy to equip the tactical teams that until recently brought larger vessels into Somali ports in wait for ransom of ship and crew.

In 2014, the UNSC finally authorized enforcement measures for the upholding of this embargo, as well as for curbing the illegal trade in charcoal from Somalia. ${ }^{3}$ The latter trade was targeted as it tends to finance the activities of the rebel-terrorists in southern Somalia known as Al-Shabaab. One of the three international maritime forces in the region - the Combined Maritime Forces ${ }^{4}$ - has to some extent applied

\footnotetext{
${ }^{1}$ In the preamble, the UNSC states that it is " $[\mathrm{g}]$ ravely alarmed at the rapid deterioration of the situation in Somalia and the heavy loss of human life and widespread material damage resulting from the conflict in the country and aware of its consequences on the stability and peace in the region"; UNSC Res. 733 of 23 January 1992 (italics in original omitted).

${ }^{2}$ UNSC Res. 733 of 23 January 1992.

${ }^{3}$ UNSC Res. 2182 of 24 October 2014.

${ }^{4}$ The others are NATO's Operation Ocean Shield (http://www.nato.int/cps/en/natohq/topics_ 48815.htm), and the European Union's Operation Atalanta (http://eunavfor.eu/).

M. Frostad (四)

Faculty of Law, K.G. Jebsen Centre for the Law of the Sea, University of Troms $\varnothing$, The Arctic University of Norway, Troms $\varnothing$, Norway

e-mail: magne.frostad@uit.no 
the charcoal authorization successfully, and its efforts have been welcomed by the UNSC. ${ }^{5}$ On the other hand, until recently, no interdiction had been undertaken in order to uphold the weapons embargo. This chapter will, among other things, seek to shed light on why that is so.

A quick terminological note might here be in order: Whereas "embargo" is used in this chapter as a reference to the order that closes a territory in relation to the goods covered by that order, maritime interdiction operations is an operational term of art that also covers a multitude of other maritime operations. ${ }^{6}$ The enforcement of an embargo is nevertheless usually referred to as interdiction activities. ${ }^{7}$ Moreover, these maritime interdiction operations are different from the jus in bello concept of naval blockade, whereby naval vessels and aircraft patrol the coastline of an enemy state in order to stop any in- and outgoing traffic from her ports. ${ }^{8}$

In the following, the chapter will commence by looking at the history of UN authorized embargos where enforcement has been contemplated through, typically, visitation of vessels and confiscation of goods violating the embargo. An issue is here the right to innocent passage in the territorial seas of the states actually enforcing the embargo, and the regime established by UNSC Res. 1973 (2011) will for this purpose be considered in some detail. The chapter will then move on to the regime adopted for Somalia, with a focus on the enforcement authority granted in UNSC Res. 2182 (2014), especially in relation to weapons etc., before some of the challenges resulting from this latter authorization are considered.

\section{The History of UN Security Council Authorized Maritime Interdictions}

\subsection{Material Scope}

To the knowledge of this author, the UN General Assembly has never sought to authorize maritime interdiction, whereas it has on some occasions exercised a role in relation to peacekeeping and the coordination of collective self-defense. On the other hand, the UNSC has set up such operations on a few occasions, and weapons embargos are the most often used form of economic sanctions authorized by the UNSC. ${ }^{9}$

\footnotetext{
${ }^{5}$ UNSC Res. 2244 of 23 October 2015, para. 19. There is no reference to this operation on the homepage of the Combined Maritime Forces (https://combinedmaritimeforces.com/).

${ }^{6}$ von Heinegg (2010), p. 375.

${ }^{7}$ McLaughlin (2009), p. 137 (under reference to Soons).

${ }^{8}$ Doswald-Beck (1995), pp. 26-27 and 176-180. The concept was in use in the Vietnam war, IranIraq war and during the 2006 Israel-Lebanon conflict; see McLaughlin (2009), p. 125, n. 2. A special instance of blockade is Israel's blockade of the Gaza strip, see Klein (2010), p. 294.

${ }^{9}$ Fleck (2013), p. 70 (with further references).
} 
The UNSC first applied this measure to the unilateral declaration of independence by the white minority of Southern Rhodesia in 1966. As a consequence of the Portuguese colonial port of Beira being essential for the supply of oil to Southern Rhodesia, the UNSC mandated in Res. 221 (1966) the British "to prevent, by the use of force if necessary, the arrival at Beira of vessels reasonably believed to carrying oil destined for Southern Rhodesia, and empowers the United Kingdom to arrest and detain the tanker known as the Joanna $V$ upon her departure from Beira in the event of her oil cargo is discharged there.,"

No authorizations were then made until the end of the Cold War when the UNSC agreed on a firm response toward Iraq for her invasion of Kuwait inter alia with Res. 665 (1990) authorizing maritime interdiction activities. In para. 1 thereof, the UNSC "[c]alls upon those Member States co-operating with the Government of Kuwait which are deploying maritime forces to the area to use such measures commensurate to the specific circumstances as may be necessary under the authority of the Security Council to halt all inward and outward maritime shipping in order to inspect and verify their cargoes and destinations and to ensure strict implementation of the provisions related to such shipping laid down in resolution 661 (1990)." 11 This formulation was used as a model until the Libyan crisis in 2011. ${ }^{12}$ During the 1990s, such authorizations were made in relation to the Federal Republic of Yugoslavia (Serbia and Montenegro), ${ }^{13}$ Haiti, ${ }^{14}$ and Sierra Leone. ${ }^{15}$

A somewhat atypical authorization was issued in 2006 when the UN Interim Force in Lebanon was granted the power to assist the Government of Lebanon, at

\footnotetext{
${ }^{10}$ UNSC Res. 221 of 9 April 1966, para. 5 (italics in original). The resolution inter alia calls upon flag states to "to ensure the diversion of their vessels reasonably believed to be carrying oil destined for Southern Rhodesia which may be en route for Beira" (para. 4). For more on the Beira patrol, as well as the argument that the UNSC acted under Art. 41, see McLaughlin (2009), pp. 134-135. In the current author's view, the better view is held by Frowein whom argues that this resolution, expressly authorizing the use of force, should instead be seen as authorized by Art. 42; see McLaughlin (2009), p. 135, n. 43.

${ }^{11}$ Italics in original not indicated. UNSR Res. 661of 6 August 1990 established economic sanctions in relations to "all commodities and products originating in Iraq or Kuwait" (para. 3 (a)), hindered similar items from being exported to Iraq and Kuwait ((c)), and stopped the transfer of financial and economic resources (para. 4). For more on this operation, see McLaughlin (2009), pp. 135-138. Dinstein holds that "[i]n practical terms, Iraq was subjected in consequence to a blockade, although Resolution 665 avoided that expression”, see Dinstein (2012), p. 320.

${ }^{12}$ Fink (2011), p. 239.

${ }^{13}$ UNSC Res. 787 of 16 November 1992, para. 12, and UNSC Res. 820 of 17 April 1993, paras. 28 and 29. Thus, even vessels merely in transit through the territorial sea of the Federal Republic of Yugoslavia (Serbia and Montenegro) were covered, thereby suspending innocent passage. See McLaughlin (2009), p. 143. On the naval interdictions activities in relation to this set of authorizations, see id., pp. 138-145.

${ }^{14}$ UNSC Res. 875 of 16 October 1993, para. 1, and UNSC Res. 917 of 6 May 1994, paras. 9 and 10.

${ }^{15}$ UNSC Res. 1132 of 8 October 1997, paras. 6 and 8. This authorization was terminated in UNSC Res. 1940 of 29 September 2010, para. 1.
} 
the latter's request, in preventing the entry into Lebanon without the government's consent of arms or related materiel. ${ }^{16}$

Another atypical situation, in that it limited the otherwise typically authorized enforcement powers significantly, was the UNSC's response to North Korea in Res. 1874 (2009). This resolution is enacted explicitly under Art. 41 and limits states to "inspect, in accordance with their national authorities and legislation, and consistent with international law, all cargo to and from the DPRK, in their territory." 17 Moreover, it calls upon states "to inspect vessels, with the consent of the flag State, on the high seas, if they have information that provides reasonable grounds to believe that the cargo of such vessels contains items the supply, sale, transfer, or export of which is prohibited." 18 The limited right of enforcement is underscored by para. 13, which "[c]alls upon all States to cooperate with inspections pursuant to paragraphs 11 and 12, and, if the flag State does not consent to inspection on the high seas, decides that the flag State shall direct the vessel to proceed to an appropriate and convenient port for the required inspection by the local authorities pursuant to paragraph 11." Klein correctly holds that the adopted approach would suffice as long as the flag state actually instructs the ship to sail for a specified port and undergo the relevant inspection. ${ }^{19}$ If the flag state abstains from doing just that, it might fall out of favors with the UNSC, but the resolution, however, does not include a right to use force against a vessel whose flag state does not consent to its inspection. In later resolutions, states are obliged to deny vessels refusing such inspection entry into their ports unless it is for the purpose of inspection of the said vessel, in case of emergency, or it is returning to its port of origination. ${ }^{20}$

Another case of maritime interdiction not exactly of the embargo kind is here the authorization granted in relation to migrant smuggling and human trafficking from Libya in UNSC Res. 2240 (2015), where vessels suspected on reasonable grounds for such may be inspected on the high seas off the coast off Libya and seized when confirmed as such after inspection. ${ }^{21}$

In February 2011, the UNSC responded to the situation in Libya by authorizing inter alia a weapons embargo under the explicit reference to UN Charter Art. $41 .^{22}$ The UN member states are in para. 9 obligated to "take the necessary measures to prevent the direct or indirect supply, sale or transfer to the Libyan Arab Jamahiriya, from or through their territories or by their nationals, or using their flag vessels or aircraft" of certain items, assistances, and personnel.

These items, assistances, and personnel are identified as "arms and related materiel of all types, including weapons and ammunition, military vehicles and

\footnotetext{
${ }^{16}$ UNSC Res. 1701 of 11 August 2006, paras. 12 and 14. On this resolution, see Fink (2013), p. 81.

${ }^{17}$ Para. 11.

${ }^{18}$ Para. 12.

${ }^{19}$ Klein (2010), p. 279.

${ }^{20}$ See e.g. UNSC Res. 2094 of 7 March 2013, para. 17.

${ }^{21}$ UNSC Res. 2240 of 9 October 2015, paras. 7, 8 and 10.

${ }^{22}$ UNSC Res. 1970 of 26 February 2011, paras. 9-14.
} 
equipment, paramilitary equipment, and spare parts for the aforementioned, and technical assistance, training, financial or other assistance, related to military activities or the provision, maintenance or use of any arms and related materiel, including the provision of armed mercenary personnel whether or not originating in their territories." 23 To this list, a range of exceptions is included in the same paragraph. Additionally, para. 10 establishes a prohibition on Libyan export of arms and related materiel.

Notice should here be made of the flexible formulation of "arms and related material of all types," which might, importantly, also cover so-called dual use objects. ${ }^{24}$ Moreover, the inclusion of personnel in the embargo-armed mercenaries-was a novelty, ${ }^{25}$ and this brought about the question of how to deal with potentially detained personnel. ${ }^{26}$

Paragraph 11 moreover authorizes "all States, in particular States neighbouring the Libyan Arab Jamahiriya, to inspect, in accordance with their national authorities and legislation and consistent with international law, in particular the law of the sea and relevant international civil aviation agreements, all cargo to and from the Libyan Arab Jamahiriya, in their territory, including seaports and airports, if the State concerned has information that provides reasonable grounds to believe the cargo contains items the supply, sale, transfer, or export of which is prohibited by paragraphs 9 or 10 of this resolution for the purpose of ensuring strict implementation of those provisions."

This later authorization is limited to "their territory" and would thus apply to the territorial sea of a member state, seemingly hindering innocent passage. Admittedly, the authorization does not specifically mention territorial seas, whereas it explicitly mentions seaports. This can be understood either as merely highlighting the most important part of the maritime area where sanctions could be enforced, i.e., not to the exclusion of, e.g., internal waters and the territorial sea, or as indicating that only port state authority was contemplated and no restrictions on innocent passage intended. As the authorization does require the state to undertake its enforcement "in accordance with their national authorities and legislation and consistent with international law, in particular the law of the sea [...]," it would seem that the answer to whether the embargo could be enforced in a coastal state's territorial sea would depend on the reach of costal state enforcement jurisdiction under the 1982 UN Convention on the Law of the Sea (UNCLOS). ${ }^{27}$

\footnotetext{
${ }^{23}$ Ibid, para 9.

${ }^{24}$ Fink (2011), pp. 252-253.

${ }^{25}$ Ibid., p. 254.

${ }^{26}$ Ibid., p. 256.

${ }^{27} 1833$ UNTS 3.
} 


\subsection{Innocent Passage}

The issue of innocent passage is regulated by UNCLOS in Arts. 18-26 and their customary international law counterparts. A starting point would here be the requirement in Art. 19 para. 1 of "[s]uch passage shall take place in conformity with this Convention and with other rules of international law." ${ }^{28}$ These "other rules of international law" may inter alia be mandatory resolutions of the UNSC. However, Res. 1970 (2011) does not grant enforcement powers in relation to the weapons embargo beyond that which was already recognized by international law. Moreover, the said embargo operations are not explicitly covered by the exceptions to innocent passage in Art. 19 para. 2. Arguably, para. 2 is not a closed list of what may be considered "prejudicial to the peace, good order or security of the coastal State" due to the flexible wording of litra 1 ("any other activity not having a direct bearing on passage"), ${ }^{29}$ but it might be seen as odd if the relevant nonmentioned situations where just slight variations of those listed. Thus, as regards the exceptions explicitly mentioned in para. 2, an antithetical approach could be held as preferable, and this would still leave room for other scenarios that are different from those identified in litras a to k. However, the very wording of litra 1 is so wide in itself ("any other activity") that it would be hard to restrict its interpretation in such a way. On the other hand, it would seem strange if the mere transport of such goods would constitute an activity "not having a direct bearing on passage."

However, no general exemption from the laws and regulations of the coastal state exists for vessels in innocent passage, ${ }^{30}$ whereas UNCLOS Art. 21 (1) (h) allows the coastal state to adopt laws and regulations regarding "the prevention of infringement of the customs, fiscal, immigration or sanitary laws and regulations of the coastal State." One approach could then be to argue that customs laws provide the required authority as - it would have to be argued-a state can make these applicable also to transshipment through its territory, if not otherwise obligated. However, such a restriction would seriously undermine the very concept of innocent passage, and this cannot have been the intention of the states negotiating UNCLOS. Tanaka moreover argues that the violation of the laws of the coastal state does not ipso facto deprive a passage of its innocent character, unless such violations fall within the scope of Art. 19. ${ }^{31}$ What does then Art. 19 allow for in such a setting? Actually, the reference in Art. 19 (2)(g) to "the loading or unloading of any

\footnotetext{
${ }^{28}$ Klein (2010), p. 278. For the view that such transport is in violation of Arts. 17, 19 and 301 due to its non-peaceful purpose, see Song (2007), pp. 116-117.

${ }^{29}$ Tanaka (2015), p. 88. This would then be in contradistinction to the 1989 USA-USSR Joint Statement on the Uniform Interpretation of Rules of International Law Governing Innocent Passage, para. 3 (http://cil.nus.edu.sg/rp/il/pdf/1989\%20USA-USSR\%20Joint\%20Statement\%20on\%20the\% 20Uniform\%20Interpretation\%20of\%20Rules\%20of\%20International\%20Law-pdf.pdf).

${ }^{30}$ Rothwell and Stephens (2016), p. 457.

${ }^{31}$ Tanaka (2015), p. 89.
} 
commodity [..] contrary to the customs [...] laws and regulations of the coastal State" would seem to limit customs powers to situations where the cargo is physically transferred off the vessel, and that is wholly different from a vessel merely sailing through the territorial sea of a state.

Be that as it may, as Art. 27 refers to "should not" as opposed to "shall not," the latter being used in Arts. 21 para. 2 and 24 para. 1, the coastal state actually has criminal jurisdiction over ships within its territorial sea also beyond the situations mentioned in para. 1 of Art. 27, although this authority should generally not be exercised for purposes outside of those mentioned in Art. 27. ${ }^{32}$ Although it might be argued that the possible reach of the laws of the coastal state should be seen in relation to Art. 19, Guilefoyld correctly points out in relation to the transport of weapons of mass destruction (WMD) that the obligations flowing from UNSC Res. 1540 means that "[i]n the context of WMD shipments passing through the territorial sea, it is exactly that capacity to act which becomes an obligation to act under UNSCR 1540." ${ }^{33}$ Moreover, a transport of WMD through the territorial sea is seen by him, for the purpose of Art. 27 para. 5, as being "continuous acts, breaches of the prohibition occurring as much within territorial waters as without." 34 The WMD regime under Res. 1540 (2004) ${ }^{35}$ and the embargo regime under, e.g., Res. 1973 (2011) are both passed under Chapter VII of the UN Charter and oblige states to take the necessary measures to stop the relevant activity. ${ }^{36}$ It might thus be argued

\footnotetext{
${ }^{32}$ Guilfoyle (2009), p. 242, and Tanaka (2015), p. 96. For the view that counter-proliferation and counter-terrorism operations are covered by Art. 27, para. 1, litras a or b, see von Heinegg (2010), pp. $378-379$.

${ }^{33}$ Guilfoyle (2009), p. 242 . This would provide a legal basis for the interdictions considered by the Proliferation Security Initiative to be consistent with international law: "To take appropriate actions to (1) stop and/or search in their internal waters, territorial seas, or contiguous zones (when declared) vessels that are reasonably suspected of carrying such cargoes [WMD, their delivery systems, or related materials] to or from states or non-state actors of proliferation concern and to seize such cargoes that are identified; and (2) to enforce conditions on vessels entering or leaving their ports, internal waters or territorial seas that are reasonably suspected of carrying such cargoes, such as requiring that such vessels be subject to boarding, search, and seizure of such cargoes prior to entry": U.S. Department of State, Statement of Interdiction Principles, 2003, No. 4, chapeau and litra d, (http://www.state.gov/t/isn/c27726.htm) (italics by author). Without this resolution, Tanaka would be right in pointing out that this self-authorization is not necessarily in accordance with international law, as Art. 19(2) does not mention WMD, and since it is debatable whether the transport of such through the territorial sea of a state is "prejudicial to the peace, good order or security of the coastal State" under Art. 19(1): Tanaka (2015), p. 393.

${ }^{34}$ Guilfoyle (2009), p. 243. See also von Heinegg (2010), p. 379.

${ }^{35}$ As continued until 2021 under UNSC Res. 1977 of 20 April 2011, para. 2.

${ }^{36}$ UNSC Res. 1540 of 28 April 2004 explicitly obliges states in para. 2 to "adopt and enforce appropriate effective laws which prohibit any non-State actor" to e.g. manufacture WMD, whereas UNSC Res. 1970 para. 9 more generally orders that states "shall immediately take the necessary measures to prevent the direct or indirect supply, sale or transfer" to Libya of the relevant items. Presumably, such measures would by necessity include the rules necessary in order to implement this obligation in domestic law, and this limits the difference between the approaches used. Admittedly, the obligation under Res. 1540 would seem to also cover criminal sanctions, whereas the normal embargo authorization might possibly be limited to non-criminal sanctions.
} 
that coastal states are obliged to use their right to legislate under Art. 27 to hinder "innocent" passage of the items covered by an embargo and that the breaching of such a UN resolution constitutes a continuous act by the vessel undertaking "innocent" passage.

\subsection{Other Aspects of the Geographical Application of the Libyan Embargo}

As regards the waters beyond the territorial sea, Fink correctly points out that the reference in Res. 1970 (2011) to "their territory" did not mandate actual enforcement at sea. ${ }^{37}$ Basically, states were thus limited to checking vessels going to their ports, or flying their own flag, unless the foreign flag state consented to such control. The states could nevertheless monitor the effectiveness of the measures through information gathering, and they could support other actors who actually had jurisdiction over potential embargo breakers in their response toward these. ${ }^{38}$

However, this situation changed with the authorization granted in Res. 1973 (2011) para. 13, where the UNSC “[c]alls upon all Member States, in particular States of the region, acting nationally or through regional organisations or arrangements, in order to ensure strict implementation of the arms embargo established by paragraphs 9 and 10 of resolution 1970 (2011), to inspect in their territory, including seaports and airports, and on the high seas, vessels and aircraft bound to or from the Libyan Arab Jamahiriya, if the State concerned has information that provides reasonable grounds to believe that the cargo contains items the supply, sale, transfer or export of which is prohibited by paragraphs 9 or 10 of resolution 1970 (2011) as modified by this resolution, including the provision of armed mercenary personnel, calls upon all flag States of such vessels and aircraft to cooperate with such inspections and authorises Member States to use all measures commensurate to the specific circumstances to carry out such inspections." 39

Thus, this resolution allows a state to also inspect foreign flagged vessels on the high seas. This is due to the general reference to "vessels" where no exception is made for those flying a foreign flag, the following reference to flag states being called upon to cooperate, and the added "all measures" authorization. With this expansion of the regime under Res. 1970 (2011) to the high seas and including the vessels of other flag states, the reference to enforcement in the territory of the state would, if not earlier, at least now include a right of the coastal state to act against vessels in innocent passage in its own territorial sea: if it can enforce the embargo where it otherwise has no sovereignty, it must even more be able to do so where it actually holds such an entitlement.

\footnotetext{
${ }^{37}$ Fink (2011), p. 242.

${ }^{38}$ Ibid., p. 243 with further references.

${ }^{39}$ Italics in original.
} 
Similarly, the reference above to the high seas does not exclude the enforcement of such powers in the exclusive economic zone (EEZ) of all other states, including the Libyan EEZ, as the high seas freedoms largely apply even in the EEZ, and consequently NATO also enforced the embargo in the Libyan EEZ. ${ }^{40}$

As there are no phrases in this resolution on Libya that geographically limit the part of the high seas to which this authorization applies, as would arguably have been the case if the formulation "to halt all inward and outward shipping" had been used, the embargo could have been enforced also on the most remote waters. ${ }^{41}$ However, the operation was in practice contained to the central Mediterranean Sea. ${ }^{42}$ The embargo was nevertheless not enforced in the Libyan territorial sea, or for that matter seemingly in the territorial sea of other states, ${ }^{43}$ as the former was understood to fall outside of the latter's authorization as it only referred to "the high seas." 44

Presumably, the territorial sea limitation in Res. 1973 (2011) could have been bypassed by the authorization granted in para. 4 to take all necessary measures to protect civilians and civilian-populated areas under threat of attack. If that is so, at the very least, such an operation would have to be closely linked to that part of the mandate, i.e., not being seen as an embargo operation. ${ }^{45}$ However, although the civilian protection authorization does not have an explicit geographical limitation as such, it nevertheless refers to civilian-populated areas, and these will almost by necessity be on land. Thus, enforcement in the territorial sea of Libya would seemingly have to relate to the halting of troops, weapons, or ammunition intended for use, preferably in the close future, against such civilians and civilian-populated areas.

A different take on the legal situation would be to consider the law of international armed conflicts to be applicable to those states upholding the weapons embargo against Libya that were also involved in the use of armed force for the protection of civilians. ${ }^{46}$ As their territories, including territorial seas, would then be covered by the area of that international armed conflict, these coastal states would be in a position to enforce visitation rights over neutral vessels under the law of neutrality, which go far beyond the rights of coastal states in relation to vessels exercising innocent passage in peacetime. Of course, such rights would also apply to the high seas. ${ }^{47}$

The authorization furthermore requires "reasonable grounds" for believing that the embargo is being broken, and this would seem to be similar to the standard used

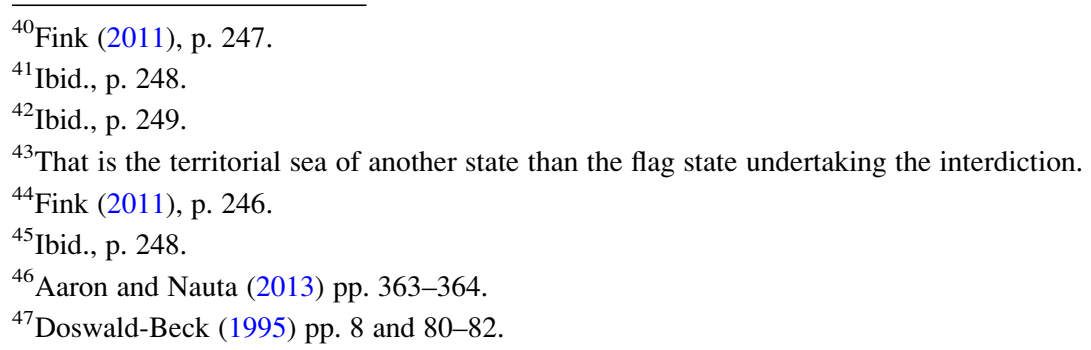


in UNCLOS Art. 110 regarding visitations. ${ }^{48}$ This threshold links back to the Beira Patrol resolutions as a blanket authority to halt every vessel would seem to have been granted by the post Beira resolutions. ${ }^{49}$ The requirement of reasonable grounds differentiates such embargos from a naval blockade. ${ }^{50}$ No difference seems here to be made between state-owned vessels and merchant vessels, but as the first category largely enjoys sovereign immunity, clear language to that effect should be expected, before interdiction of state vessels is considered authorized.

The Libyan embargo was loosened in Res. 2009 (2011), ${ }^{51}$ whereas NATO ceased its maritime embargo operation after military operations were terminated in Res. 2016 (2011), ${ }^{52}$ even though the economic sanctions continued. ${ }^{53}$ In relation to illicitly exported crude oil from Libya, a rather narrowly drafted authorization was provided by the UNSC in Res. 2146 (2014).

\subsection{The Authorization to Use Force}

In the resolution authorizing the Beira patrol, use of force is explicitly referred to ("by the use of force if necessary"), and the resolution is passed under reference to the "situation constitute[ing] a threat to the peace," although no explicit reference is made to Arts. 41 or $42 .{ }^{54}$ The other abovementioned resolutions went from vague references to Chapter VII through a reference to other resolutions, ${ }^{55}$ via a reference to the situation in the relevant state as constituting a threat to international peace and security, ${ }^{56}$ to explicit mentioning of Chapter VII. ${ }^{57}$ Thus, it must be decided through a rather contextual analysis whether the UNSC has authorized an embargo under Art. 41 or Art. 42. ${ }^{58}$

McLaughlin raises the question of whether authorizations to implement economic sanctions should rather be seen as uses of force different from military

\footnotetext{
${ }^{48}$ Fink (2011), p. 250.

${ }^{49} \mathrm{Id}$.

${ }^{50}$ Ibid., pp. $250-251$.

${ }^{51}$ UNSC Res. 2009 of 16 September 2011, para. 13.

${ }^{52}$ UNSC Res. 2016 of 27 October 2011, para. 5.

${ }^{53}$ Fink (2011), p. 241.

${ }^{54}$ Fink nevertheless holds that this resolution was passed under reliance on Art. 41. See Fink (2011), p. 244.

${ }^{55}$ UNSC Res. 665 of 25 August 1990.

${ }^{56}$ UNSC Res. 1701 of 11 August 2006.

${ }^{57}$ UNSC Res. 787 of 16 November 1992, para. 12, UNSC Res. 820 of 17 April 1993 (text between paras. 9 and 10), UNSC Res. 875 of 16 October 1993, UNSC Res. 917 of 6 May 1994, UNSC Res. 1132 of 8 October 1997.

${ }^{58}$ For a similar view, see Fink (2013), p. 83.
} 
sanctions under Art. $42,{ }^{59}$ and he also holds that Art. 41 and Art. 42 should be considered as a continuum making it less important with a clear-cut separation. ${ }^{60}$ However, with the development of the expanded notion of Art. 42, where also situations below the threshold of full-scale warfare are covered, it is submitted that the better view would be to consider maritime interdiction activities authorized to use force as having been granted under Art. $42 .{ }^{61}$ Correspondingly, the lack of a direct authorization to use force through the traditional formulations used for that purpose would arguably leave naval vessels intent on enforcing a UNSCestablished embargo without the right to use any force in so doing. ${ }^{62}$

Res. 1970 (2011) is nevertheless clear as it refers explicitly to Art. 41, whereas Res. 1973 (2011) merely applies an unspecified reference to Chapter VII as such. The reference therein to "all necessary measure" (paras. 4 and 8) and "all measures commensurate to the specific circumstances" (para. 13) nevertheless shows that Art. 42 is the basis for Res 1973 (2011). ${ }^{63}$ The latter formulation is a slight rephrasing of the formulation used in relation to Iraq (Res. 665 (1990)), which instead used these words in para. 1: "[U]se such measures commensurate to the specific circumstances as may be necessary." The chosen wording might be seen as a combination of the usual phrasing for such operations and the wording traditionally used for enforcement operations ("all necessary means/measures"). ${ }^{64}$

\section{Somalia}

\subsection{General Aspects}

Although the counterpiracy resolutions of the UNSC are the Somalia-related resolutions which have generated the most comments and discussion, ${ }^{65}$ resolutions are passed in relation to Somalia at least on two other interlinked topics as well: foreign troops authorized to help the new government regain control over Somali territory, and the weapons and charcoal embargo.

The weapons embargo is established in Res. 733 (1992) "for purposes of establishing peace and stability in Somalia" 66 and constitutes "a general and complete embargo on all deliveries on weapons and military equipment to

\footnotetext{
${ }^{59}$ McLaughlin (2009), p. 132. For seemingly the same view, see Klein (2010), p. 280.

${ }^{60}$ McLaughlin (2009), p. 133.

${ }^{61}$ Fink (2013), pp. 84-87.

${ }^{62}$ In this direction, see ibid., p. 92.

${ }^{63}$ For a similar view, see Fink (2011), p. 251.

${ }^{64} \mathrm{Id}$.

${ }^{65}$ The current resolution is UNSC Res. 2246 of 10 November 2015.

${ }^{66}$ UNSC Res. 733 of 23 January 1992, para. 5.
} 
Somalia., ${ }^{, 67}$ Res. 1425 (2002) expands the embargo to also cover the financing of all acquisitions and deliveries of weapons and military equipment, ${ }^{68}$ as well as "direct or indirect supply to Somalia of technical advice, financial and other assistance, and training related to military activities." 69

Not surprisingly, the UNSC has made a number of exceptions from the embargo: ${ }^{70}$ the foreign counterpiracy presence, ${ }^{71}$ the presence of the African Union, ${ }^{72} \mathrm{UN}$ personnel, ${ }^{73}$ and the European Union Training Mission in Somalia. ${ }^{74}$ Similarly excepted are the security forces of the Somali federal authorities, although some categories of weapons must be approved beforehand by the committee established to oversee that embargo,${ }^{75}$ and where the equipment etc. will solely be used in the development of institutions of the Somalia security sector. ${ }^{76}$

In Res. 751 (1992), the UNSC also established the abovementioned committee ${ }^{77}$ which was merged with the committee on Eritrea following Res. 1907 (2009). ${ }^{78}$ Furthermore, the UNSC requested the UN Secretary General (UNSG) to establish a panel of experts in Res. 1425 (2002) to inter alia investigate violations of the embargo, and through the continuation of the mandate of this panel, ${ }^{79}$ the UNSG was requested to establish a Monitoring Group in Res. 1519 (21) to undertake largely the same activities. ${ }^{80}$ The mandate of the Monitoring Group is

${ }^{67} \mathrm{Id}$.

${ }^{68}$ UNSC Res. 1425 of 22 July 2002, para. 1.

${ }^{69}$ Ibid., para. 2.

${ }^{70}$ The newest list is found in UNSC Res. 2244 of 23 October 2015, paras. 1-10.

${ }^{71}$ UNSC Res. 2184 of 12 November 2014, paras. 15.

${ }^{72}$ UNSC Res. 1744 of 21 February 2007, para. 6, and UNSC Res. 1772 of 20 August 2007, paras. 11. Including the strategic partners of this force: UNSC Res. 2093 of 6 March 2013, para. 36, and UNSC Res. 2111 of 24 July 2013, para. 10 (b) and (c).

${ }^{73}$ UNSC Res. 2093 of 6 March 2013, para. 37.

${ }^{74}$ UNSC Res. 2111 of 24 July 2013, para. 10 (d).

${ }^{75}$ UNSC Res. 2093 of 6 March 2013, para. 33, UNSC Res. 2111 of 24 July 2013, paras. 6 and 14, UNSC Res. 2142 of 5 March 2014, para. 2, UNSC Res. 2182 of 24 October 2014, para. 1, and UNSC Res. 2244 of 23 October 2015, paras. 1 and 2. The resolutions do not explain why these weapons are mentioned and the formulations are not always optimal; see Stockholm International Peace Research Institute, UN arms embargo on Somalia, 14 November 2014, downloadable from http://www.sipri.org/databases/embargoes/un_arms_embargoes/somalia.

${ }^{76}$ UNSC Res. 2111 of 24 July 2013, para. 11 (a). See also UNSC Res. 2142 of 5 March 2014, paras. 2 and 8 . The resolutions do not elaborate on what would be subsumed under the notion of "in service of its security forces"; see Stockholm International Peace Research Institute (2014). The system is continued in UNSC Res. 2244 of 23 October 2015, para. 2. The Somali authorities are required to provide information regarding such acquisitions, but these requirements are not always met. See UNSC Res. 2182 of 24 October 2014, para. 2, and UNSC Res. 2244 of 23 October 2015, para. 6.

${ }^{77}$ UNSC Res. 751 of 24 April 1992, para.11.

${ }^{78}$ See The Security Council Committee pursuant to resolutions 751 (1992) and 1907 (2009) concerning Somalia and Eritrea (https://www.un.org/sc/suborg/en/sanctions/751).

${ }^{79}$ UNSC Res. 1425 of 22 July 2002, para. 3.

${ }^{80}$ UNSC Res. 1519 of 16 December 2003, para. 2. 
expanded in Res. 2036 to also include the charcoal export, as the UNSC expresses "concern that charcoal exports from Somalia are a significant revenue source for $\mathrm{Al}$ Shabaab and also exacerbate the humanitarian crisis." 81

The current mandate expires on 16 December $2016,{ }^{82}$ and until recently, no separate enforcement powers were provided in relation to this embargo, in contradistinction to the embargos of the Federal Republic of Yugoslavia (Serbia and Montenegro) and Iraq. ${ }^{83}$ Here, it might have been argued that the reference in Res. 733 to "immediately implement a general and complete embargo on all deliveries of weapons and military equipment» included the right to stop and search the vessels suspected of transporting weapons to Somalia, as the term «implement" would seemingly have to include this ${ }^{84}$ However, Klein is correct in pointing out that as the UNSC at the time typically explicitly authorized the halting of vessels and inspection of cargo, such an interpretation would be improper. ${ }^{85}$ As a consequence, there has never been a lack of weapons. ${ }^{86}$ Lately, it might even seem as if Somali pirates have financed violations of this embargo. ${ }^{87}$

\subsection{The Reach of the Enforcement Authority Granted in UNSC Res. 2182}

The absent enforcement powers were rectified in para. 15 of Res. 2182 of 24 October 2014, which establishes a maritime interdiction regime to be enforced by states, acting nationally or through voluntary multinational naval partnerships, in cooperation with the Federal Government of Somalia. That government must also notify the UNSG thereof, and the latter office must subsequently notify all Member States accordingly. So far, the Somali government has considered the following Combined Maritime Forces states as acceptable for the purpose of this authorization: Australia, Bahrain, Canada, Denmark, France, Germany, Italy, Japan, the Netherlands, New Zealand, Norway, Portugal, Saudi Arabia, Singapore, Spain, Turkey, UAE, the UK and the USA. ${ }^{88}$

The aim of the mandate is to ensure strict implementation of the arms embargo on Somalia and the charcoal ban. For this purpose, the vessels and aircraft of these states may inspect, without undue delay, in Somali territorial waters and on the high

\footnotetext{
${ }^{81}$ UNSC Res. 2036 of 22 February 2012, p. 3. See also paras. 22 and 23.

${ }^{82}$ UNSC Res. 2244 of 23 October 2015, para. 31.

${ }^{83}$ Brown (2011), p. 75.

${ }^{84}$ Klein (2010), p. 278.

${ }^{85} \mathrm{Id}$.

${ }^{86}$ UNSC Res. 1851 of 16 December 2008, para. 9.

${ }^{87}$ Ibid., p. 2, and UNSC Res 2020 of 22 November 2011, para. 6.

${ }^{88}$ Report of the Monitoring Group on Somalia and Eritrea pursuant to Security Council resolution 2182 (2014): Somalia, UN Doc. S/2015/801, 19 October 2015, p. 294.
} 
seas off the coast of Somalia extending to and including the Arabian Sea and Persian Gulf, certain types of vessels. ${ }^{89}$

Although commentators have held earlier that UN-authorized maritime interdiction may be undertaken in the territorial sea of third states even when this geographic extension is not explicitly mentioned in the mandate ${ }^{90}$ the very reference to this power only in relation to "Somali territorial waters and on the high seas off the coast of Somalia extending to and including the Arabian sea and Persian Gulf" ${ }^{\prime 91}$ would seem to argue against the authorization applying to, e.g., the territorial sea of Djibouti. ${ }^{92}$

The vessels covered by the authorization are described in para. 15 as bound to or from Somalia, and which the enforcers have reasonable grounds to believe are

(a) carrying charcoal from Somalia in violation of the charcoal ban;

(b) carrying weapons or military equipment to Somalia, directly or indirectly, in violation of the arms embargo on Somalia; and

(c) carrying weapons or military equipment to individuals or entities designated by the Committee established pursuant to Resolutions 751 (1992) and 1907 (2009).

That a specific vessel has undertaken such a transport before is not in itself sufficient to establish such grounds, but it would definitely help in establishing that threshold as long as corroborating evidence exists. As regards weapons and military equipment onboard vessels, the UNSC clarifies in Res. 2244 (2015) para. 3 that "the entry into Somali ports for temporary visits of vessels carrying arms and related materiel for defensive purposes does not amount to a delivery of such items in violation of the arms embargo on Somalia, provided that such items remain at all times aboard such vessels."

In para. 16 of Res. 2182 (2014), the UNSC moreover calls upon "all Flag States of such vessels to cooperate with such inspections, requests Member States to make good faith efforts to first seek the consent of the vessel's Flag State prior to any inspections pursuant to paragraph 15, authorizes Member States conducting inspections pursuant to paragraph 15 to use all necessary measures commensurate with the circumstances to carry out such inspections and in full compliance with international humanitarian law and international human rights law, as may be applicable, and urges Member States conducting such inspections to do so without causing undue delay to or undue interference with the exercise of the right of innocent passage or freedom of navigation." As the embargo enforcers are not party to the noninternational armed conflict in Somalia, or in an armed conflict with the weapons and charcoal transporters, the reference to international humanitarian law would seem unnecessary.

\footnotetext{
${ }^{89}$ Para. 15.

${ }^{90}$ McLaughlin (2009), p. 152.

${ }^{91}$ UNSC Res. 2182 of 24 October 2014, para. 15.

${ }^{92}$ In a similar manner the UNSC explicitly authorized counter-piracy operations in Somali "territorial waters" in UNSC Res. 1816 of 2 June 2008, para. 7 (a).
} 
Furthermore, para. 19 grants authority to seize or dispose of any item covered by the embargo which is found during the inspections. Paragraph 19 clarifies that para. 15 also "includes the authority to divert vessels and their crews, to a suitable port to facilitate such disposal, with the consent of the port State" and "the authority to use all necessary measures to seize items pursuant to paragraph 17 in the course of inspections." If the authorization is put to use, obligations of reporting are incurred by the state whose vessels or aircraft carry out the inspection. ${ }^{93}$ Thus, an interdicting state must promptly send a notification and later a more lengthy report to the said committee. Presumably, it is possible to provide the required information without having to divulge more classified information than does the Monitoring Group in its reports. ${ }^{94}$

Here, the UNSC strongly underlines that the authorization follows an invitation from Somali authorities, that it only applies to Somalia, and that it cannot be seen as establishing international customary law. ${ }^{95}$

The abovementioned authorization was renewed in Res. $2244(2015)^{96}$ but has until recently hardly been acted upon. ${ }^{97}$

\section{Challenges}

\subsection{General Issues}

No reports are made of weapons-related interdictions during the period of October 2014 to October $2015,{ }^{98}$ whereas the charcoal ban resulted in "a perceptible deterrent effect." 99

In relation to the latter, the Monitoring Group observes that "[i]ntelligence shared by the combined Maritime Forces with the Monitoring Group led to the successful interception of the MSV Raj Milan (MMSI 419956307) at Port Rashid in Dubai, United Arab Emirates, with support from United Arab Emirates authorities. The issue of the disposal of seized charcoal, the absence of legal follow-through, and the difficulties in identifying a State willing to accept diverted ships have, however, hampered initial efforts to operationalize maritime interdiction. Minimizing the interaction between the naval forces and the vessels carrying charcoal

\footnotetext{
${ }^{93}$ UNSC Res. 2182 of 24 October 2014, para. 19.

${ }^{94}$ Information considered strictly confidential is simply left out of the public version of the report.

${ }^{95}$ UNSC Res. 2182 of 24 October 2014, para. 21.

${ }^{96}$ UNSC Res. 2244 of 23 October 2015, para. 20.

${ }^{97}$ Report of the Monitoring Group on Somalia and Eritrea pursuant to Security Council resolution 2182 (2014): Somalia, UN Doc. S/2015/801, 19 October 2015, pp. 41-44 and 293-322.

${ }^{98}$ Ibid., p. 41.

${ }^{99}$ Ibid., p. 43.
} 
remains critical for an effective implementation of the charcoal ban." ${ }^{\prime 00}$ The Monitoring Group also highlights the problems with identifying potentially embargo-breaking vessels as dhows transporting cargo to and from the southern parts of Somalia tend to not use the automatic identification system. ${ }^{101}$ This might at least partially be an attempt to avoid detection by the embargo enforcers. ${ }^{102}$

Basically, the port state acted here within its ordinary authority, after having been tipped off by the Combined Maritime Forces, but it gained a right to confiscate the said cargo through the UNSC resolution. Some of the vessels enforcing the embargo are parties to the 1950 European Convention on Human Rights (ECHR), ${ }^{103}$ but to the extent that no interdiction at sea is undertaken by such a state party, only a limited amount of issues would seem to arise in relation to that instrument. Rather, the human rights obligations of the relevant port state will apply.

Here, some of the challenges are largely of a practical nature: how to identify the vessels and how to motivate coastal states to allow the vessel into port for the relevant control. As regards the former, a legal problem admittedly arises in relation to reasonable grounds for believing that a vessel is in breach of the embargo since it might be harder to connect landside intelligence regarding a specific shipment with the very vessel later found at sea or in port.

As regards the weapons embargo, transforming the authorization into action has proved difficult. The Monitoring Group identifies the challenges as "how to interpret and apply certain provisions of the authorisation, particularly with respect to dealing with individuals found on board interdicted vessels, and the documentation and disposal of weaponry, including in the context of European Union legal requirements." 104 In a footnote, the Monitoring Group furthermore highlights issues like "the obligations of flag states, the need for the conduct of inspections to accord with international humanitarian and human rights law, seizure and disposal and the reporting requirements consonant on such inspections."105

Of importance is naturally the fact that the UNSC has not authorized a deviation from otherwise applicable human rights obligations, or for that matter international humanitarian law. Thus, human rights will inter alia limit the amount of force, armed or otherwise, to be used during the boarding of a suspected vessel, regulate the possibility of detaining individuals and the procedural rights held by these, the detainees' right (should they be prosecuted) to a fair trial, and their right to property.

Some of the pertinent legal issues indicated by the Monitoring Group are considered below.

\footnotetext{
${ }^{100}$ Ibid., pp. 43-44 and 316.

${ }^{101}$ Ibid., p. 44.

${ }^{102} \mathrm{Id}$.

${ }^{103}$ Convention for the Protection of Human Rights and Fundamental Freedoms, CETS No. 5.

${ }^{104}$ Report of the Monitoring Group on Somalia and Eritrea pursuant to Security Council resolution 2182 (2014): Somalia, UN Doc. S/2015/801, 19 October 2015, p. 294.

${ }^{105}$ Ibid., p. 294, n 152.
} 


\subsection{To Whom the Honor?}

A typical issue nowadays is whether the relevant naval vessel may be held to represent another entity than its flag state, thereby possibly passing on the responsibility for the detention etc. to that other entity. The Combined Maritime Forces would not seem to be an entity with a sufficient international legal personality to shoulder such obligations, ${ }^{106}$ whereas the states participating on EU naval operations seem to have diverging views on whether the individual is apprehended by a state or the EU itself. ${ }^{107}$ The looseness of the UNSC control with the enforcers of this operation also argues against placing sole responsibility on the UN. It is to be presumed that any detention will be considered as having been undertaken by the state to which the interdicting vessel belongs. As regards naval vessels and the extraterritorial application of the ECHR, it would seem clear that they bring persons apprehended by such vessels within the "jurisdiction" of ECHR Art. 1. ${ }^{108}$

\subsection{Flag State Consent}

As regards the UNSC requesting the states taking upon themselves to enforce the embargo that they "make good faith efforts to first seek the consent of the vessel's Flag State prior to any inspections" (para. 16), it must be stressed that this is not an obligation. If time allows, it would nevertheless be proper to seek such an authorization, and in order to make this process efficient, contact should be made in advance with the authorities of the neighboring states for this purpose, as well as with other states where the relevant vessels might be flagged. Just as important is nevertheless agreeing in advance with the neighboring states of Somalia for the bringing into their ports of vessels following boarding.

\subsection{Detention of Persons}

As mentioned above, this issue was raised in relation to the mercenary embargo of Libya, although to the knowledge of this author no such detentions took place. Admittedly, the authorization to detain is not as explicit in relation to the charcoal/ weapons embargo of Somalia as it was with Libya, but it is submitted that detention

\footnotetext{
${ }^{106}$ For a general discussion of whether another entity is to be held responsible, see Serdar Mohammed and Others v. Secretary of State for Defence, Court of Appeal (Civil Division), 30 July 2015, [2015] EWCA Civ 843, paras. 50-66.

${ }^{107}$ Petrig (2014), pp. 120 and 121, n 434.

${ }^{108}$ For a good overview of the case law in general, see Serdar Mohammed and Others v. Secretary of State for Defence, Court of Appeal (Civil Division), 30 July 2015, [2015] EWCA Civ 843 , paras. $83-106$.
} 
is nevertheless authorized by the terms "to use all necessary measures commensurate with the circumstances." 109 Thus, an ECHR member state detaining an individual in these circumstances will not be required to identify one of the alternatives in ECHR Art. 5, para. 1 as applicable. However, nothing is inter alia provided in relation to how long individuals found onboard interdicted vessels may be detained, and therefore the other parts of Art. 5 will largely apply without abridgement.

As they have been acting in violation of a UNSC-authorized embargo, it might seem proper to use any valid criminal option available. Violating the embargo is nevertheless no international crime, ${ }^{110}$ and even if it was, the prosecution would have to take place before national courts as no international court exists with jurisdiction to try such cases. A successful prosecution would then depend on inter alia domestic provisions, making it a crime to violate the embargo, and it might be expected that such provisions are lacking in many national legal systems. If relevant domestic provisions do exist, it is likely that the individuals will be handed over to the flag state of the vessel they sailed on, their state of nationality, or the relevant port state. ${ }^{111}$ However, few states will presumably be interested in prosecuting these individuals, and it would therefore be natural for them to be released by the port state authorities after the necessary statements etc. have been taken or by the naval vessel itself if this can take place at an earlier point in time and in a way that would respect the human rights of the detainees. As the list of information that the interdicting party is obliged to report under para. 20 is rather long, it is to be expected that the detention of the said individuals will last more than a few hours at the very least, and thus that the persons will seldom be released before the vessel has made port.

An outstanding question is, typically where the vessel is sold off at an auction, how to bring these individuals back to where they belong.

\subsection{Seizure and Disposal}

An important aspect of inspections is provided for in Res. 2182 (2014) para. 19, where it follows that the state may "seize and dispose of (such as through

\footnotetext{
${ }^{109} \mathrm{~A}$ similar reasoning is applied in relation to detention in Afghanistan by ISAF where the authorization is largely similarly phrased, see ibid., paras. 146-148.

${ }^{110}$ The obligations undertaken by the 2013 Arms Trade Treaty, UN Doc. A/RES/67/234B of 11 June 2013, Art. 6, para. 1 at least point is that direction: "A State Party shall not authorize any transfer of conventional arms covered under Article 2 (1) or of items covered under Article 3 or Article 4, if the transfer would violate its obligations under measures adopted by the United Nations Security Council acting under Chapter VII of the Charter of the United Nations, in particular arms embargoes".

${ }^{111}$ Even if the flag state of the naval vessel undertaking the interdiction has such a domestic provision, the experience of state's lack of enthusiasm in prosecuting pirates does not argue for them easily using such an authorization.
} 
destruction, rendering inoperable or unusable, storage, or transferring to a State other than the originating or destination States for disposal) any items identified in inspections pursuant to paragraph 15, the delivery, import or export of which is prohibited by the arms embargo on Somalia or the charcoal ban, [that the UNSC also] authorizes Member States to collect evidence directly related to the carriage of such items in the course of such inspections, and decides that charcoal seized in accordance with this paragraph may be disposed of through resale which shall be monitored by the Somalia and Eritrea Monitoring Group."

This authorization resembles to a certain extent the right granted for the purpose of counterpiracy operations against the Somali piracy plague. ${ }^{112}$ The wording from Res. 2020 (2011) is illustrating. Besides calling on states to deploy naval vessels, arms, and military aircraft to fight piracy and armed robbery at sea, the UNSC here also refers to another mode of fighting: "through seizures and disposition of boats, vessels, arms and other related equipment used in the commission of piracy and armed robbery at sea off the coast of Somalia, or for which there are reasonable grounds for suspecting such use."113

Fink holds in relation to the piracy authorization that "[i]t might be clear from the purposes of the mandate that certain goods may not pass, which thus implies that those goods can be seized, but it is questionable whether a $\mathrm{UN}$ resolution is also sufficient basis to form a title that allows for either immediate change of legal possession or for the goods to become res nullius immediately after the capture. If this is not the case, seizing and destroying captured goods, considering it as «booty» or anything else before any further judicial process has taken place, is, although a good military practical solution, done on rather shaky legal grounds." 114

Actually, the formulation in Res. 2020 (2011) above would seem to grant a right to preventively seize and dispose over vessels and weapons also were only reasonable suspicion of piracy can be established. This would then be in contrast to the general duty to compensate if the suspicion has been unfounded following UNCLOS Art. 110. ${ }^{115}$ The same regime would apply to the weapons and charcoal embargo. This threshold of suspicion is probably lower that what is normal in many national legal systems in relation to a permanent loss of items following suspicion of criminal acts. ${ }^{116}$ As breaching the said embargo might not even be illegal under domestic law, this gives grounds to pause.

It should also be noted that the new charcoal/weapons authorization diverges in a number of ways from the one used in relation to the Somali piracy threat. Firstly,

\footnotetext{
${ }^{112}$ UNSC Res. 1846 of 2 December 2008, para. 9, UNSC Res. 1851 of 16 December 2008, para. 2, UNSC Res. 1897 of 30 November 2009, para. 3, UNSC Res. 1950 of 23 November 2010, para. 4, and UNSC Res. 2020 of 22 November 2011, para. 7.

${ }^{113}$ UNSC Res. 2020 of 22 November 2011, para. 7. Italics in original have not been reproduced. Variations of this formulation are used in UNSC Res. 2077 of 21 November 2012, para. 10, UNSC Res. 2125 of 18 November 2013, para. 10, UNSC Res. 2184 of 12 November 2014, para. 11, and UNSC Res. 2246 of 10 November 2015, para. 12.

${ }^{114}$ Fink (2010), p. 21.

${ }^{115}$ Guilfoyle (2009), pp. 68-69.

${ }^{116}$ Friman and Lindborg (2013), p. 184.
} 
the charcoal/weapons authorization exemplifies disposal "such as through destruction, rendering inoperable or unusable, storage, or transferring to a State other than the originating or destination States for disposal." This largely reflects the wording used in UNSC Res. 1970 (2011) para. 12 regarding the arms embargo of Libya. Secondly, Res. 2182 (2014) emphasizes "the importance of all Member States [...] taking the necessary measures to ensure that no claim shall lie at the instance of Somalia [etc.] [...] in connection with any contract or other transaction where its performance was prevented by reason of the measures imposed by this resolution or previous resolutions." 117 Thirdly, the right to collect evidence is explicitly mentioned. Fourthly, in relation to charcoal, the right to resale under certain conditions is specifically catered for, although that mode of disposal is not obligatory.

One question is here whether the phrases from the UNSC resolutions regarding the charcoal/weapons embargo are sufficient to establish an exception for the right to property under the ECHR Protocol 1 Art. 1 should the relevant acts be considered as falling within the jurisdiction of the state party under ECHR Art. 1.

As this would be a case of potential loss of property, the situation would seem to be covered by the rule found in Art. 1, No. 1. Central questions are then if a limitation of the right to property may be found in international law or whether it instead must be found in domestic law. Additionally, are the words used in the resolutions sufficiently clear if the limitation as such may be found in international law? The answer to both questions is probably yes. In relation to the similarly phrased piracy resolutions, Petrig nevertheless points out that the general reference in the resolutions to carry out the use of force "consistent with this resolution and international law" prohibits a state from dealing with these cases in a summary way. ${ }^{118}$

However, it would seem as if the European Court of Human Rights has instead used the rule in Art.1 No. 2 when dealing with seizure of goods being smuggled, fines, etc. ${ }^{119}$ Since the seizure does not necessarily take place after a decision by a court, the criminal alternative ("penalties") in No. 2 would not necessarily be applicable. ${ }^{120}$ Should this rule nevertheless be applied, the questions raised above would have to be addressed, as well as procedural requirements like the ability to refer the case to a court. ${ }^{121}$ The right to use such procedural rights is often illusory

\footnotetext{
${ }^{117}$ Para. 18.

${ }^{118}$ Petrig (2015), p. 853.

${ }^{119}$ See as an example Handyside v. the United Kingdom, Appl. No. 5493/72, Plenary court judgment, 7 December 1976, para. 63 (confiscation and destruction of books), Agosi v. the United Kingdom, Appl. No. 9118/80, Chamber judgment, 24 October 1986, para. 51 (confiscation of gold coins smuggled into the United Kingdom), and Air Canada v. the United Kingdom, Appl. No. 9/1994/456/537, Chamber judgment, 26 April 1995, paras. 33-34 (which admittedly dealt with limitations on use until a penalty had been paid).

${ }^{120}$ Phillips v. the United Kingdom, Appl. No. 41087/98, Chamber judgment, 5 July 2001, para. 51, and Friman and Lindborg (2013), p. 185, n. 55.

${ }^{121}$ Agosi v. the United Kingdom, Appl. No. 9118/80, Chamber judgment, 24 October 1986, paras. 55, 59-60, and Air Canada v. the United Kingdom, Appl. No. 9/1994/456/537, Chamber judgment, 26 April 1995, para. 44.
} 
for apprehended pirates, ${ }^{122}$ and this would be similar for those apprehended in relation to the charcoal/weapons ban. Moreover, problems may arise in relation to the assessment of proportionality if items are damaged or destroyed during an interdiction operation, either because more force is used than necessary or because the item is later destroyed and thereby not returned to an innocent third party from whom it was stolen. ${ }^{123}$ This is especially troublesome where the individual is later found not to have been guilty of violating the ban on charcoal/weapons. ${ }^{124}$ Although this right to "summary" seizure and loss is used quite extensively in counterpiracy operations, ${ }^{125}$ it would seem as if EU forces on such operations for these reasons apply a higher threshold than the one that follows from the UNSC resolutions, ${ }^{126}$ and this they will presumably do also in relation to the charcoal/weapons ban.

As indicated, the charcoal, weaponry, etc. found would have to be documented and disposed of in a satisfactory way. The better way of handling the issue of charcoal is probably, as indicated in para. 19, to auction it off. ${ }^{127}$ After having deducted the costs of the state auctioning it away, it would be proper to transfer the remaining sum to the Somali Federal Government, but no such obligation exists. As regards weapons, such cargo could presumably be granted the Federal Government of Somalia, and since the said weapons and ammunition is probably rather new and in larger quantity than what has so far been encountered in pirate skiffs, this might be a natural disposal of the equipment. However, there is no obligation on the interdicting states to do so, and they might just as well decide to destroy the cargo. In both instances, the UNSC highlights in para. 19 the importance of disposing equipment etc. in "an environmentally responsible manner."

\section{Conclusions}

There are probably many places around the world where additional weapons are what is least needed and where correspondingly an effectively enforced weapons embargo should be welcomed by the world at large. And from a practical point of view, this will often be the only measure that casualty-avoiding wealthy nations are motivated to participate in the enforcement of. ${ }^{128}$ Among all the challenges that

\footnotetext{
${ }^{122}$ Friman and Lindborg (2013), p. 185.

${ }^{123}$ Bodini (2011), pp. 842-843 (in relation to piracy). ${ }^{124}$ Id.

${ }^{125}$ Friman and Lindborg (2013), p. 185.

${ }^{126} \mathrm{Id}$.

${ }^{127}$ This is what happened with the cargo of MSV Raj Milan — a vessel found to have violated the charcoal embargo, see Report of the Monitoring Group on Somalia and Eritrea pursuant to Security Council resolution 2182 (2014): Somalia, UN Doc. S/2015/801, 19 October 2015, p. 316.

${ }^{128}$ The problem is largely that an effective embargo will freeze the relationship of strength between the contenders, leaving an edge to the major party, which might be seen as action in violation of relevant rules meant to protect individuals and groups from oppression. Also, the arms embargo of
} 
must be overcome in order to achieve such enforcement, the legal issues deserve more attention than they have been given so far.

In relation to the implementation hurdles identified in its report on Somalia, the Monitoring Group states that "development of a specific implementation assistance notice should be considered. In the interim the sharing of real time information with the Monitoring Group on vessels which may be operating in violation of the arms embargo should be encouraged." 129 Some suggestions are also given in relation to the charcoal ban, ${ }^{130}$ but the Group did not suggest new formulations to be used in upcoming UNSC resolutions for the clarification of the issues raised in chapter 4, and the wording used in Res. 2244 of 23 October 2015 offers little help.

For member states to the ECHR inclined on limiting the scrutiny of human rights institutions, one option would be to seek a transformation of the operation into something resembling a maritime KFOR or ISAF, as these operations have or may presume to be left largely outside the assessment of at least the European Court of Human Rights, as it seemingly will be holding the UN responsible instead. Note, however, that the UN Human Rights Committee may often be an alternative avenue for applicants as it states in General Comment No. 31 that a troop-contributing nation will still be held responsible in such operations. ${ }^{131}$

In relation to seizure and disposal, especially when undertaken in a UN operation as opposed to a coalition of the willing, the UNSC should consider authorizing a sanction panel, ${ }^{132}$ which would have the final say in whether detention and seizure were legal; undertake the disposal of the seized items in a prize court fashion; and offer compensation where the embargo enforces were found to be at fault. The panel could be a sub-body of the sanction committee, be located in Djibouti where many of the vessels dock, but deploy (under prearrangements with the neighboring port states) to where the relevant vessel has been brought for adjudication.

Be that as it may, although the current enforcement mandate is welcome, weapons will probably still cross into Somali territory over its borders with Kenya, Ethiopia, and-to a lesser extent-Djibouti, which are presumably not sufficiently policed. The key to avoiding this, as well as piracy and other kinds of organized crime, is achieving a well working state on the Horn of Africa.

\section{Postscript}

Since this chapter was finalized, the UNSC has anew authorized enforcement of the weapons embargo of Libya (Res. 2292 (2016)) where much of the terminology of

\footnotetext{
inter alia Bosnia Herzegovina hindered that state's right to respond in self-defense against the attacks it underwent at the hands of inter alia Serb military entities. See Fleck (2013), p. 70.

${ }^{129}$ Report of the Monitoring Group on Somalia and Eritrea pursuant to Security Council resolution 2182 (2014): Somalia, UN Doc. S/2015/801, 19 October 2015, p. 295.

${ }^{130}$ Ibid., p. 50.

${ }^{131}$ Human Rights Committee, General Comment No. 31 [80] The Nature of the General Legal Obligation Imposed on States Parties to the Covenant, UN. Doc. CCPR/C/21/Rev.1/Add. 13, p. 4.

${ }^{132}$ Fink has previously indicated this as a general weakness with the UN embargo regime. See Fink (2010), pp. 20-21.
} 
Res. 1973 is reused. However, good-faith efforts to obtain flag state consent prior to inspection must now be made (para. 3), and the category of vessels able to undertake such inspections is also identified (para. 6), whereas it is explicitly mentioned that the authorization does not apply to vessels benefitting from sovereign immunity (para. 7). Explicit reference is also made of the authority to divert the vessel to a suitable port (para. 8), and this provision may have been imported from Res. 2182 (2014) (para. 19).

Also, the Combined Maritime Forces have on two occasions in March 2016 (the Australian HMAS Darwin and the French FS Provence) seized large amounts of weapons. The vessels used for smuggling were first inspected in order to determine their nationality, and when deemed stateless, the dhows were searched and the weapons then found were seized. ${ }^{133}$

Acknowledgements The author would like to thank the peer reviewer for helpful suggestions.

\section{References}

\section{Journals and Articles}

Aaron MR, Nauta DRD (2013) Operational challenges of the law on air warfare: the example of operation unified protector. Military Law Law War Rev 52:353-377

Bodini SP (2011) Fighting maritime piracy under the European convention on human rights. Eur J Int Law 22:829-848

Fink MD (2011) UN-mandated maritime arms embargo operations in operation unified protector. Military Law Law War Rev 50:237-260

Fink MD (2013) Maritime embargo operations: naval implementation of UN sanctions at sea under articles 41 and 42 of the UN Charter. Neth Int Law Rev 60:73-92

Song Y-H (2007) The U.S.-led proliferation security initiative and UNCLOS: legality, implementation, and an assessment. Ocean Dev Int Law 38:101-141

\section{Books and Chapters}

Brown N (2011) Jurisdictional problems relating to non-flag state boarding of suspected ships in international waters: a practitioner's observations. In: Symmons CR (ed) Selected contemporary issues in the law of the sea. Martinus Nijhoff, Leiden, pp 69-82

Dinstein Y (2012) War, aggression and self-defence, 5th edn. Cambridge University Press, Cambridge

Doswald-Beck L (ed) (1995) San Remo manual on international law applicable to armed conflicts at sea. Cambridge University Press, Cambridge

Fleck D (2013) Arms control and disarmament law: its role in addressing new security threats. Military Law Law War Rev 52:61-80

\footnotetext{
${ }^{133}$ See https://combinedmaritimeforces.com for details.
} 
Friman H, Lindborg J (2013) Initiating criminal proceedings with military forces: some legal aspects of policing Somali pirates by navies. In: Guilefoyle D (ed) Modern piracy: legal challenges and responses. Edward Elgar, Cheltenham, pp 172-201

Guilfoyle D (2009) Shipping interdiction and the law of the sea. Cambridge University Press, Cambridge

Klein N (2010) Maritime security and the law of the sea. Oxford University Press, Oxford

McLaughlin R (2009) United Nations naval peace operations in the territorial sea. Martinus Nijhoff, Leiden

Petrig A (2014) Human rights and law enforcement at sea: arrest, detention and transfer of piracy suspects. Brill Nijhoff, Leiden

Petrig A (2015) Piracy. In: Rothwell DR, Oude Elferink AG, Scott KN, Stephens T (eds) The Oxford handbook of the law of the sea. Oxford University Press, Oxford, pp 843-865

Rothwell DR, Stephens T (2016) The international law of the sea, 2nd edn. Hart Publishing, Oxford and Portland

Tanaka Y (2015) The international law of the sea, 2nd edn. Cambridge University Press, Cambridge von Heinegg WH (2010) Maritime interception/interdiction operations. In: Gill TD, Fleck D (eds) The handbook of the international law of military operations. Oxford University Press, Oxford, pp 375-393

\section{Online Publications}

USA-USSR Joint Statement on the Uniform Interpretation of Rules of International Law Governing Innocent Passage (http://cil.nus.edu.sg/rp/il/pdf/1989\%20USA-USSR\%20Joint\% 20Statement $\% 20$ on $\% 20$ the $\% 20$ Uniform $\% 20$ Interpretation $\% 20$ of $\% 20$ Rules $\% 20$ of $\% 20$ International\%20Law-pdf.pdf)

U.S. Department of State, Statement of Interdiction Principles (http://www.state.gov/t/isn/c27726.htm) Stockholm International Peace Research Institute, UN arms embargo on Somalia, 14 November 2014, downloadable from http://www.sipri.org/databases/embargoes/un_arms_embargoes/somalia

The Security Council Committee pursuant to resolutions 751 (1992) and 1907 (2009) concerning Somalia and Eritrea (https://www.un.org/sc/suborg/en/sanctions/751)

\section{Other}

Convention for the Protection of Human Rights and Fundamental Freedoms, CETS No. 5

UN Convention on the Law of the Sea 1833 UNTS 3

Arms Trade Treaty, UN Doc. A/RES/67/234B of 11 June 2013

UNSC Res. 221 of 9 April 1966

UNSR Res. 661 of 6 August 1990

UNSC Res. 665 of 25 August 1990

UNSC Res. 733 of 23 January 1992

UNSC Res. 751 of 24 April 1992

UNSC Res. 787 of 16 November 1992

UNSC Res. 820 of 17 April 1993

UNSC Res. 875 of 16 October 1993

UNSC Res. 917 of 6 May 1994

UNSC Res. 1132) of 8 October 1997

UNSC Res. 1425 of 22 July 2002

UNSC Res. 1519 of 16 December 2003

UNSC Res. 1540 of 28 April 2004 
UNSC Res. 1701 of 11 August 2006

UNSC Res. 1744 of 21 February 2007

UNSC Res. 1772 of 20 August 2007

UNSC Res. 1816 of 2 June 2008

UNSC Res. 1846 of 2 December 2008

UNSC Res. 1851 of 16 December 2008

UNSC Res. 1897 of 30 November 2009

UNSC Res. 1940 of 29 September 2010

UNSC Res. 1950 of 23 November 2010

UNSC Res. 1970 of 26 February 2011

UNSC Res. 1977 of 20 April 2011

UNSC Res. 2009 of 16 September 2011

UNSC Res. 2016 of 27 October 2011

UNSC Res. 2020 of 22 November 2011

UNSC Res. 2036 of 22 February 2012

UNSC Res. 2077 of 21 November 2012

UNSC Res. 2093 of 6 March 2013

UNSC Res. 2094 of 7 March 2013

UNSC Res. 2111 of 24 July 2013

UNSC Res. 2125 of 18 November 2013

UNSC Res. 2142 of 5 March 2014

UNSC Res. 2146 of 19 March 2014

UNSC Res. 2182 of 24 October 2014

UNSC Res. 2184 of 12 November 2014

UNSC Res. 2240 of 9 October 2015

UNSC Res. 2244 of 23 October 2015

UNSC Res. 2246 of 10 November 2015

UNSC Res. 2292 of 14 June 2016

Report of the Monitoring Group on Somalia and Eritrea pursuant to Security Council Resolution 2182 (2014): Somalia, UN Doc. S/2015/801, 19 October 2015

Human Rights Committee, General Comment No. 31 [80] The Nature of the General Legal Obligation Imposed on States Parties to the Covenant, UN. Doc. CCPR/C/21/Rev.1/Add. 13

Handyside v. the United Kingdom, Appl. No. 5493/72, Plenary court judgment, 7 December 1976 Agosi v. the United Kingdom, Appl. No. 9118/80, Chamber judgment, 24 October 1986

Air Canada v. the United Kingdom, Appl. No. 9/1994/456/537, Chamber judgment, 26 April 1995 Phillips v. the United Kingdom, Appl. No. 41087/98, Chamber judgment, 5 July 2001

Serdar Mohammed and Others v. Secretary of State for Defence, Court of Appeal (Civil Division), 30 July 2015, [2015] EWCA Civ 843

Open Access This chapter is licensed under the terms of the Creative Commons AttributionNonCommercial 4.0 International License (http://creativecommons.org/licenses/by-nc/4.0/), which permits any noncommercial use, sharing, adaptation, distribution and reproduction in any medium or format, as long as you give appropriate credit to the original author(s) and the source, provide a link to the Creative Commons license and indicate if changes were made.

The images or other third party material in this chapter are included in the chapter's Creative Commons license, unless indicated otherwise in a credit line to the material. If material is not included in the chapter's Creative Commons license and your intended use is not permitted by statutory regulation or exceeds the permitted use, you will need to obtain permission directly from the copyright holder. 